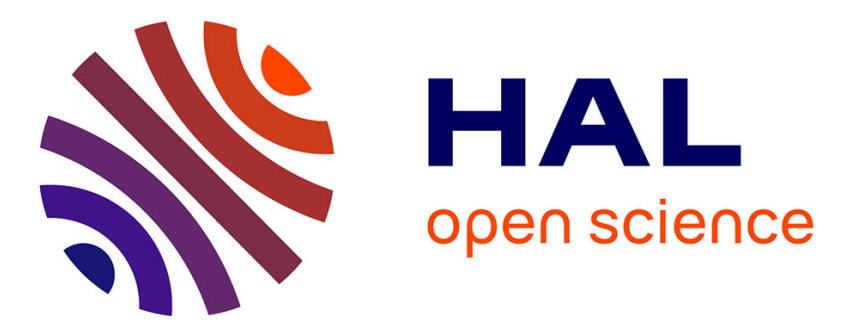

\title{
Intraoperative glycemic control without insulin infusion during pediatric cardiac surgery for congenital heart disease.
}

Thierry V Scohy, Hanna D Golab, Mohamud Egal, Johanna J.M. Takkenberg, Ad J.J.C. Bogers

\section{To cite this version:}

Thierry V Scohy, Hanna D Golab, Mohamud Egal, Johanna J.M. Takkenberg, Ad J.J.C. Bogers. Intraoperative glycemic control without insulin infusion during pediatric cardiac surgery for congenital heart disease.. Pediatric Anesthesia, 2011, 21 (8), pp.872. 10.1111/j.1460-9592.2011.03571.x . hal00628685

\section{HAL Id: hal-00628685 \\ https://hal.science/hal-00628685}

Submitted on 4 Oct 2011

HAL is a multi-disciplinary open access archive for the deposit and dissemination of scientific research documents, whether they are published or not. The documents may come from teaching and research institutions in France or abroad, or from public or private research centers.
L'archive ouverte pluridisciplinaire HAL, est destinée au dépôt et à la diffusion de documents scientifiques de niveau recherche, publiés ou non, émanant des établissements d'enseignement et de recherche français ou étrangers, des laboratoires publics ou privés. 


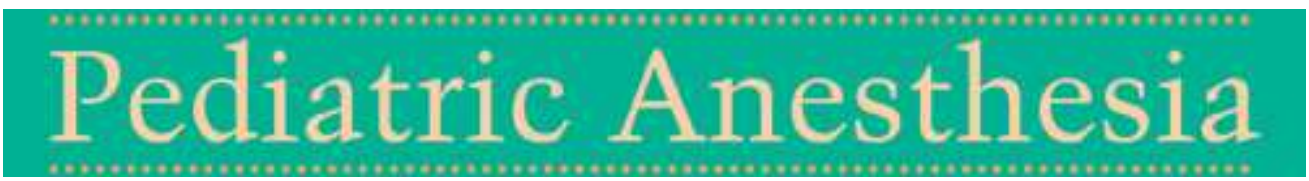

\section{Intraoperative glycemic control without insulin infusion during pediatric cardiac surgery for congenital heart disease.}

\begin{tabular}{|r|l|}
\hline Journal: & Pediatric Anesthesia \\
\hline Manuscript ID: & PAN-2010-0336.R4 \\
\hline Wiley - Manuscript type: & Original Paper \\
\hline Date Submitted by the \\
Author: & 10 -Feb-2011 \\
\hline Complete List of Authors: & $\begin{array}{l}\text { Scohy, Thierry; Erasmus Medical Center, Anesthesiology } \\
\text { Golab, Hanna; ErasmusMC, Cardiothoracic surgery } \\
\text { Egal, Mohamud; ErasmusMC, Anesthesiology } \\
\text { Takkenberg, Johanna; ErasmusMC, Cardiothoracic surgery } \\
\text { Bogers, Ad; ErasmusMC, Cardiothoracic surgery }\end{array}$ \\
\hline Key Words: & congenital heart disease < Cardiac, glycemic control, intraoperative \\
\hline
\end{tabular}


Thierry V. Scohy MD ${ }^{\text {a }}$, Hanna D. Golab ${ }^{\text {}}$, Mohamud Egal ${ }^{\text {a }}$, Johanna J.M. Takkenberg

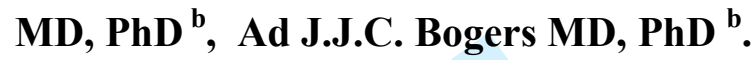

${ }^{a}$ Department of Anaesthesiology, Erasmus University Medical Center, Rotterdam, The Netherlands.

${ }^{\mathrm{b}}$ Department of Cardiothoracic Surgery, Erasmus University Medical Center, Rotterdam, The Netherlands..

Shortened title: intraoperative glucose control, pediatric cardiac surgery

Conflict of interest: There is no conflict of interest.

Corresponding author: Department of Anaesthesiology, Room Bd 581, Erasmus Medical

Center, Dr Molenwaterplein 40, 3015CE Rotterdam, The Netherlands.

Tel +31 107 040704, Fax +31 107035240 .

E-mail address: t.scohy@erasmusmc.nl 


\begin{abstract}
Background: Many studies are reporting that the occurrence of hyperglycemia in the postoperative period is associated with increased morbidity and mortality rates in children after cardiac surgery for congenital heart disease. This study sought to determine blood glucose levels in standard pediatric cardiac anesthesiological management without insulin infusions.
\end{abstract}

Methods: The study population consisted of 204 consecutive pediatric patients aged from 3 days to 15.4 years undergoing open cardiac surgery for congenital heart disease between June 2007 and January 2009. Glucose containing fluids were not administrated intraoperatively, all patients received high dose of opioids (sufentanil $10 \mathrm{mcg} / \mathrm{kg}$ ) and steroids $(30 \mathrm{mg} / \mathrm{kg}$ methylprednisolone) iv. Glucose levels were measured before CPB, 10 minutes after initiation of $\mathrm{CPB}$, every hour on $\mathrm{CPB}$, post $\mathrm{CPB}$ and on arrival at Intensive Care Unit (ICU).

Results: Intraoperatively only 1 patient had a glucose level $<50 \mathrm{mg} / \mathrm{dl}(=34.2 \mathrm{mg} / \mathrm{dl}), 57 / 204$ patients $(27.9 \%)$ had at least one intraoperative glucose $>180 \mathrm{mg} / \mathrm{dl}$, but only 12 patients (5.8\%) had a glucose level $>180 \mathrm{mg} / \mathrm{dl}$ at ICU arrival. 30 days mortality was $1.5 \%(3 / 204)$. Younger age, lower body weight and lower CPB temperature were associated with hyperglycemia at ICU arrival, as were higher RACHS and Aristotle severity scores.

Conclusion: A conventional (no insulin, no glucose) anesthetic management seems sufficient in the vast majority of patients (96.5\%). Special attention should be paid to small neonates with complex congenital heart surgery, in whom insulin treatment may be contemplated 


\section{Background}

Several studies report that the occurrence of hyperglycemia in the postoperative period is associated with increased morbidity and mortality rates in children after cardiac surgery for congenital heart disease [1-4]. However, no association with intraoperative management or complexity of congenital heart disease has yet been assessed.

Lately there is concern that glycemic control in the peri-operative period, aiming at avoiding hyperglycemia while maintaining a strict euglycemic target, could place patients at risk for hypoglycemia and hereby enhance the risk for adverse outcome [1,2,5-7]. In addition, the NICE-sugar Study [6] found that postoperative intensive glucose control (81 to $108 \mathrm{mg} / \mathrm{dl} ; 4.5$ to $6.0 \mathrm{mmol} / \mathrm{l}$ ) increased mortality and a moderate blood glucose target $<180 \mathrm{mg} / \mathrm{dl}$ $(<10 \mathrm{mmol} / \mathrm{l})$ resulted in lower mortality in adults.

Infants often have reduced glycogen reserve, especially in the setting of physiological stress, and insulin therapy in this setting may place them at risk for developing hypoglycemia [8]. To our knowledge there is only one published report on adverse outcome and intraoperative glucose levels during complex congenital heart surgery in children [2]. In this light we report on our pediatric cardiac anesthesiological management and the blood glucose levels in 204 consecutive children during open cardiac surgery for congenital heart disease, exploring the association between blood glucose and complexity of congenital heart disease patient and preoperative characteristics. 


\section{Methods}

The study population consisted of 204 consecutive pediatric patients aged from 3 days to 15.4 years undergoing open cardiac surgery for congenital heart disease between June 2007 and January 2009. The retrospective study was approved by the Erasmus MC internal review board and the need for informed consent was waived. Pre-operatively children were not allowed any food at least four hours before induction of anesthesia, but were allowed glucose containing clear liquids until two hours before anesthesia. None of the patients received premedication. Before induction of anesthesia, all patients were monitored with a five-lead, two-channel electrocardiogram, non-invasive blood pressure measurement, and pulse oximetry. All patients without a peripheral intravenous (iv) access had an inhalation induction with sevoflurane $8 \%$. After insertion of iv catheter, midazolam $0.3 \mathrm{mg} / \mathrm{kg}$, sufentanil 2 $\mathrm{mcg} / \mathrm{kg}$, pancuronium $0.15 \mathrm{mg} / \mathrm{kg}$ and $40 \mathrm{mg} / \mathrm{kg}$ cefazoline were administrated and sevoflurane was stopped. Patients were nasotracheally intubated and pressure controlled ventilated after an alveolar recruitment strategy [9]. Anesthesia was maintained with midazolam $0.1 \mathrm{mg} / \mathrm{kg} / \mathrm{h}$. Invasive monitoring via $20 \mathrm{G}$ arterial line in the femoral artery, an internal jugular central venous catheter, a Foley bladder catheter, a rectal temperature probe and the Oldelft MicroMultiplane TEE probe (Oldelft, Delft, The Netherlands) were routinely inserted [10].

Before incision we administered another $0.2 \mathrm{mg} / \mathrm{kg}$ midazolam, $2 \mathrm{mcg} / \mathrm{kg}$ sufentanil together with $30 \mathrm{mg} / \mathrm{kg}$ magnesium sulfate, $30 \mathrm{mg} / \mathrm{kg}$ methylprednisolone, $1 \mathrm{mg} / \mathrm{kg}$ ranitidine and $1 \mathrm{mg} / \mathrm{kg}$ furosemide. All patients received a continuous infusion of $\mathrm{NaCl} 0.9 \%$ during the preincision period. Glucose containing fluids were not administrated intraoperatively. In case of normovolemic hypotension we administered $1 \mathrm{mcg} / \mathrm{kg}$ phenylephrine, in case of hypertension sevoflurane was used. Before initiation of CPB we administered $2 \mathrm{mcg} / \mathrm{kg}$ sufentanil, 0.1 
$\mathrm{mg} / \mathrm{kg}$ midazolam, $300 \mathrm{IU}$ heparine and $20 \mathrm{mg} / \mathrm{kg}$ cefazoline, . Another bolus of $2 \mathrm{mcg} / \mathrm{kg}$ sufentanil and $0.1 \mathrm{mg} / \mathrm{kg}$ midazolam was administrated during rewarming phase of CPB and dobutamine $4 \mathrm{mcg} / \mathrm{kg} / \mathrm{min}$ was started. After declamping of the aorta enoximone $0.2 \mathrm{mg} / \mathrm{kg}$ was administrated.

Pediatric CPB circuits consisted always of hollow-fiber oxygenator with hard-shell reservoir, a roller pump and arterial filter. The circuits were phosphorylcholine coated. Prime volumes varied depending on patient's body weight; for neonates and infants up to $10 \mathrm{~kg}-300 \mathrm{ml}$, for patients up to $25 \mathrm{~kg}-450 \mathrm{ml}$ and for patients up to $45 \mathrm{~kg}-850 \mathrm{ml}$. Prime was composed of homologous red blood cells (RBCs), fresh-frozen plasma (FFP) and Gelofusine (B.Braun, Melsungen, Germany) and was always completed with $0.5 \mathrm{~g} / \mathrm{kg} \mathrm{BW}$ mannitol, $0.5 \mathrm{~g} / \mathrm{kg} \mathrm{BW}$ human albumin 20\% solution (Sanquin, Amsterdam, The Netherlands), 4.2 IU heparine / mL priming volume and $2-5 \mathrm{ml} \mathrm{NaHCO} 38.4 \%$.

Administration of RBCs, FFP, crystalloids or colloids during CPB was based upon the system working volumes and target values for hematocrit during the CPB (not lower than $0.28 \mathrm{~L} / \mathrm{L}$ for acyanotic as well as cyanotic patients). Human albumin was added to maintain the colloid oncotic pressure $\geq 15 \mathrm{mmHg}$. In accordance with protocol no modified ultrafiltration and no antifibrinolitic medication was used.

Activated clotting time was monitored during the bypass and maintained above $480 \mathrm{sec}$. Nonpulsatile $\mathrm{CPB}$, with mild hypothermia of $28^{\circ} \mathrm{C}$ to $32^{\circ} \mathrm{C}$, was performed with blood flow rates between $1.8 \mathrm{~L} / \mathrm{min} / \mathrm{m}^{2}$ to $3.2 \mathrm{~L} / \mathrm{min} / \mathrm{m}^{2}$ to maintain venous oxygen saturation above $70 \%$ and mean arterial pressure between 40 to $60 \mathrm{mmHg}$. In case of a deep hypothermic circulatory arrest (DHCA) patients were cooled till $18^{\circ} \mathrm{C}$ nasopharyngeal and $21^{\circ} \mathrm{C}$ rectal temperature. Anterograde cerebral perfusion was utilized when appropriate. During CPB $\alpha$-stat regulation was employed together with target value for arterial oxygen tension of $20 \mathrm{kPa}$. Myocardial protection was achieved with non-glucose containing crystalloid cardioplegia. Cardioplegic 
solution was preferably sucked into the cell-saving device (CS). Perioperative blood loss was collected and processed by CS device, together with residual volume of the CPB circuit. The CS product was always considered first line blood replacement therapy.

After weaning from CPB another $2 \mathrm{mcg} / \mathrm{kg}$ sufentanil and $0.1 \mathrm{mg} / \mathrm{kg}$ midazolam was administered. All patients received a total of $10 \mathrm{mcg} / \mathrm{kg}$ of sufentanil throughout the whole surgical procedure.

Glucose levels were measured before $\mathrm{CPB}, 10$ minutes after initiation of CPB, every hour on $\mathrm{CPB}, 10$ minutes after administrating $4 \mathrm{mg} / \mathrm{kg}$ Protamine and on arrival at Intensive Care Unit (ICU).

In line with previous publications, we defined the following blood glucose categories: severe hypoglycemia (<30mg/dl; $1.7 \mathrm{mmol} / \mathrm{l})$, moderate hypoglycemia $(30-60 \mathrm{mg} / \mathrm{dl} ; 1.7-3.3$ mmol/l)), euglycemia (60-125 mg/dl; 3.3-6.9 mmol/l), mild hyperglycemia (126-139 mg/dl; 6.9-7.7 mmol/l), moderate hyperglycemia (140-179 mg/dl; 7.7-9.9 mmol/L), or severe hyperglycemia $(>180 \mathrm{mg} / \mathrm{dl},>9.9 \mathrm{mmol} / \mathrm{l})[2-5,11]$. For reasons of safety a $2 \mathrm{ml} / \mathrm{kg}$ glucose $10 \%$ solution was given when blood glucose level dropped under $50 \mathrm{mg} / \mathrm{dl}(2.8 \mathrm{mmol} / \mathrm{l})$.

\section{Statistical analyses}

All statistical analyses were performed with SPSS 15.0 (SPSS Inc, Chicago, IL, USA). Continuous variables are displayed as mean (SD), or median and interquartile range, categorical variables are displayed as proportions. The One-Sample Kolmorogov-Smirnov Test was used to analyse distribution of continuous variables. In case of a normal distribution comparison of continuous variables was done using the independent samples T-test, otherwise the Mann-Whitney U-test was used. 
The Spearman Correlation test was applied to assess correlation between blood glucose level on arrival at ICU, Length of stay in the hospital (LOS), ICU days, highest intraoperative blood glucose against age, weight, Aristotle complex score, RACHS score, CPB time, aortic cross clamp time (AoX), lowest intraoperative body temperature, and cyanotic/acyanotic CHD.

Univariable linear regression was applied to assess influence of cyanotic/acyanotic CHD, age, weight, Aristotle complex score, RACHS score, CPB time, aortic cross clamp time (AoX), lowest intraoperative body temperature, intraoperative blood glucose levels $(<60 \mathrm{mg} / \mathrm{dl})$, intraoperative blood glucose levels $(<75 \mathrm{mg} / \mathrm{dl})$, moderate intraoperative blood glucose levels $(>140 \mathrm{mg} / \mathrm{dl})$ and severe intraoperative blood glucose levels $(>180 \mathrm{mg} / \mathrm{dl})$ as independent variables on LOS, ICU days, extubation time and mortality as dependent variables. Univariable binary logistic regression analysis was used to study potential determinants of blood glucose level $>180 \mathrm{mg} / \mathrm{dl}$ on arrival at ICU. The following factors were considered as potential determinants: patient age, weight, Aristotle score, RACHS score, CPB time, AoX time, lowest intraoperative body temperature, blood glucose level before CPB as covariates was used.

Graphs were constructed with Graphpad software package (version 4.0, Graphpad Software Inc.,San Diego, USA).

\section{Results}

204 consecutive pediatric patients from $2.4 \mathrm{~kg}$ to $45 \mathrm{~kg}$ (130 male/ 74 female) (cyanotic versus acyanotic lesions 95/109) operated for congenital heart disease on CPB at the Thoraxcenter Rotterdam The Netherlands were included. Patients demographics, surgical procedure code by Aristotle Complexity Score [12], RACHS (risk adjustment for surgery for 
congenital heart disease) [13], CPB time, AoX time and lowest body temperature, blood glucose levels, LOS, IC stay are listed in Table 1. According to the Kolmogorov-Smirnov Test all groups of Table 1 are not normally distributed except for blood glucose level on arrival at ICU. Operations by RACHS-1 category are shown in table 2.

\section{Table 1: Patients demographics and operative details}

$\mathrm{SD}=$ standard deviation; $\mathrm{IQR}=$ Interquartile range; $\mathrm{RACHS}=$ risk adjustment for surgery for congenital heart disease; $\mathrm{CPB}=$ cardiopulmonary bypass; $\mathrm{AoX}=$ aortic cross clamp time; $\mathrm{DHCA}=$ deep hypothermic cardiac arrest; ICU = intensive care unit, $\mathrm{LOS}=$ length of stay in hospital, $\mathrm{IC}=$ intensive care.

\section{Table 2: Individual procedures by RACHS-1 category}

$\mathrm{ASD}=$ atrial septal defct, $\mathrm{CAVSD}=$ complete atrioventricular septal defect, TAPVR=Total anomalous pulmonary venous return, $\mathrm{TGA}=$ transposition of great arteries, $\mathrm{TOF}=$ tetralogy of Fallot, VSD=ventricular septal defect.

Box plots of per-operative and on arrival at ICU blood glucose levels are displayed in figure 1. No patients received insulin during surgery.

Fifty-seven of the 204 patients $(27.9 \%)$ had at least one intraoperative glucose level $>180$ $\mathrm{mg} / \mathrm{dl}(10 \mathrm{mmol} / \mathrm{l}), 132 / 204$ patients $(64 \%)$ had at least one intraoperative glucose level > 140 $\mathrm{mg} / \mathrm{dl}(7.7 \mathrm{mmol} / \mathrm{l})$, but only 12 patients $(5.8 \%)$ had a glucose level $>180 \mathrm{mg} / \mathrm{dl}(10 \mathrm{mmol} / \mathrm{l})$ on arrival at ICU (table 3), 59 patients (28.9\%) had a glucose level $>140 \mathrm{mg} / \mathrm{dl}(7.7 \mathrm{mmol} / \mathrm{l})$ on arrival at ICU.

Intraoperatively only 1 patient (a 2 year old boy with ASD) had a blood glucose level $<50$ $\mathrm{mg} / \mathrm{dl}(2.8 \mathrm{mmol} / \mathrm{l})$. We measured $34.2 \mathrm{mg} / \mathrm{dl}$ and after administration of $2 \mathrm{ml} / \mathrm{kg}$ glucose $10 \%$ blood glucose level rose to $48.6 \mathrm{mg} / \mathrm{dl}$ where after another glucose bolus was administrated and blood glucose level rose to $120 \mathrm{mg} / \mathrm{dl}$.

Figure 1: Intraoperative and ICU arrival blood glucose levels. 
Table 3: Data of patients with hyperglycemia $>180 \mathrm{mg} / \mathrm{dl}$ at ICU arrival.

$\mathrm{ASD}=$ atrial septal defect; Switch= arterial switch operation; ALCAPA= abnormal left coronary artery from the pulmonary artery; VSD= ventricular septal defect; $\mathrm{CoA}=$ aortic coarctation; $\mathrm{PDA}=$ patent ductus arteriosus; $\mathrm{AP}$ window=aortic pulmonary window; $\mathrm{TOF}=$ tetralogy of Fallot; corr. Ao Arch= correction aortic arch, $\mathrm{RACHS}=$ risk adjustment for surgery for congenital heart disease, $\mathrm{CPB}=$ cardiopulmonary bypass, AoX= Aortic crossclamping, $\mathrm{DHCA}=$ deep hypothermic cardiac arrest, $\mathrm{ACP}=$ antegrade cerebral perfusion, glc $\mathrm{IC}=\mathrm{blood}$ glucose on Intensive Care arrival.

Nine out of 204 patients had Deep Hypothermic Cardiac Arrest (DHCA), of which 5/9 (56\%) had blood glucose levels $>180 \mathrm{mg} / \mathrm{dl}(10 \mathrm{mmol} / \mathrm{l})$ on arrival at ICU, while only 7 of 195 $(3.5 \%)$ of the patients who did not undergo DHCA had blood glucose levels $>180 \mathrm{mg} / \mathrm{dl}$ on arrival at ICU.

Of the 204 patients 142 had representative extubation times (table 1), the other 62 patients received supplemental sedation for early transportation to the children ICU (logistic problem), or needed supplemental sedation because of their actual clinical condition or both.

30 days mortality was $1.5 \%$ (3/204); one sudden death 23 days postoperative after good recovery from TOF repair, one death a week after Norwood procedure due to respiratory infections complicated with necrotic enterocolitis and 1 death due to a mediastinale hemorrhage after Norwood procedure which needed postoperative ECMO support. Factors potentially associated with hyperglycemia (blood glucose level $>180 \mathrm{mg} / \mathrm{dl}$ ) on arrival at ICU are shown in table 4. Patients age $<30$ days had higher glucose levels on ICU arrival compared to patients age $>30$ days $(156.1 \pm 54.1$ versus $126.2 \pm 30.5 ; \mathrm{p}=0.001)$. Patients weighing 5 kilos or less had higher glucose levels on ICU arrival compared to patients weighing more than 5 kilos $(139.0 \pm 44.1$ versus $125.5 \pm 29.8 ; \mathrm{p}=0.008)$.

Table 5 displays the correlation results between intraoperative blood glucose levels and LOS, ICU days, extubation time and mortality. All correlations were either nonsignificant or at the most very weak (Spearman's Rho $<0.30)$. Linear regression suggested that neither lower intraoperative blood glucose levels $(<60$ or $<75$ $\mathrm{mg} / \mathrm{dl})$ nor higher intraoperative blood glucose levels $(>140$ or $>180 \mathrm{mg} / \mathrm{dl})$ had influence on 
LOS, ICU stay, mortality or extubation time (Table 6).

Table 4: Logistic regression analysis (blood glucose $>180 \mathrm{mg} / \mathrm{dl}$ at ICU arrival as dependent variable)

RACHS $=$ risk adjustment for surgery for congenital heart disease, $\mathrm{CPB}=$ cardiopulmonary bypass, $\mathrm{AoX}=$ Aortic crossclamping, $\mathrm{DHCA}=$ deep hypothermic cardiac arrest, $\mathrm{ACP}=$ antegrade cerebral perfusion, glc $\mathrm{IC}=$ blood glucose on Intensive Care arrival. $\mathrm{B}=$ sample regression coefficient, S.E.= standard error, Sig. = two-sided $\mathrm{P}$ value or observed significance level, $\operatorname{Exp}(B)=$ exponentiation of the B coefficient, C.I. $=$ confidence interval.

Table 5: Correlation analysis results of intraoperative blood glucose versus LOS, ICU days, extubation time and mortality.

Table 6: Linear regression analysis results: Lower $(<60$ and $<75 \mathrm{mg} / \mathrm{dl})$ and higher intraoperative blood glucose levels $(>140$ and $>180 \mathrm{mg} / \mathrm{dl})$ versus $\mathrm{LOS}$, ICU stay, mortality or extubation time.

$\mathrm{B}=$ sample regression coefficient, S.E. $=$ standard error, Sig. $=$ two-sided $\mathrm{P}$ value or observed significance level, Beta $=$ standardized coefficient, C.I. $=$ confidence interval.

Blood glucose levels at ICU arrival were associated with longer ICU stay $(\mathrm{p}=0.04)$ (Figure 2).

Figure 2: Blood glucose levels at ICU arrival versus ICU days.

\section{Discussion}

Stress, steroids and administration of glucose are conditions that are associated with hyperglycemia in the neonate. High circulating levels of cortisol and catecholamines (adrenaline and noradrenaline) have the reverse action to insulin, rendering the baby insulin resistant and catabolic, and in addition the latter directly suppress insulin release. 
The study shows that with a conventional (no insulin, no glucose) pediatric cardiac anesthetic approach there is little risk for intraoperative hypoglycaemia during pediatric cardiac surgery for congenital heart disease. However, frequent blood glucose monitoring is appropriate. Since all patients received $30 \mathrm{mg} / \mathrm{kg}$ methylprednisolone iv before going on CPB and since steroids use in pediatric cardiac surgery is still controversial [20,21], additional benefit in preventing hyperglycemia might be achieved by withholding steroids in pediatric cardiac surgery. In addition, severe hyperglycemia on ICU arrival was uncommon, but comparable with the paper of DeCampli et al. [14], younger patients ( $<30$ days) and lower weights $(<5$ kilos) were associated with a higher risk for hyperglycemia on ICU arrival.

High doses of opioids (sufentanil $10 \mathrm{mcg} / \mathrm{kg}$ ) attenuate the physiologic response to stress in infants undergoing cardiac surgery [16-18]. On the other hand there is concern that high dose opioids may influence extubation time and ICU stay. But, even with high dose opioids, all our 142 pediatric patients, that did not received additional sedations, were extubated within 21.1 hours after arrival at ICU. High doses of sufentanil together with nonglucose iv fluids contributed to the high percentage (95\%) of our patients that had glucose level $<180 \mathrm{mg} / \mathrm{dl}(10 \mathrm{mmol} / \mathrm{l})$ on arrival at ICU. These findings together with the NICESUGAR study [6] results, which showed that a blood glucose target of $<180 \mathrm{mg} / \mathrm{dl}(<10$ mmol/l) resulted in lower mortality in adult patients than did a more strict blood glucose target. Endorse the belief that a conventional (no insulin, no glucose) anesthetic management seems sufficient in the vast majority of patients [6].

Special attention should be paid to neonates who need DHCA for surgical repair and are at an increased risk of postoperative hyperglycemia ( 5 out of 9 DHCA patients had blood glucose levels $>180 \mathrm{mg} / \mathrm{dl}$ at ICU arrival). In these patients a more strict intraoperative glycemic target ((90-140 mg/dl; 5-7.7 mmol/l) [5], (110-126 mg/dl; 6.1-7 mmol/l) [2]) might be useful, requiring insulin infusions and Real-Time continuous glucose monitoring [8]. 


\section{Balancing between perioperative hypoglycaemia and hyperglycemia}

Our study did not support the hypothesis that lower- or higher intraoperative blood glucose levels would be associated with a longer duration of postoperative hospitalisation. According to the results of Polito et al.[2] 23\% of our patients are at greater risk for adverse outcome (mortality and composite morbidity variable) because of an intraoperative glucose level $<75 \mathrm{mg} / \mathrm{dl}(4.1 \mathrm{mmol} / \mathrm{l})$. Our results do not support this, patients whose minimum intraoperative glucose level was $<75 \mathrm{mg} / \mathrm{dl}$ or even $<60 \mathrm{mg} / \mathrm{dl}$ did not show any association with LOS, ICU stay, extubation time or mortality. Avoiding lower glucose levels $(<75 \mathrm{mg} / \mathrm{dl})$ can only be achieved by administrating glucose containing fluids in the pre CPB period, which will increase the occurrence of hyperglycemic periods [15].

Twenty-eight percent of our patients had at least one intraoperative glucose level > $180 \mathrm{mg} / \mathrm{dl}(10 \mathrm{mmol} / \mathrm{l})$ and $64 \%$ had at least one episode of blood glucose levels $>140 \mathrm{mg} / \mathrm{dl}$ which, in accordance to the results of Polito et al.[2], is not associated with adverse events. We only found a weak association between blood glucose levels at ICU arrival and ICU days. On the other hand various other reports have shown an association between postoperative hyperglycemia and enhanced extubation times, LOS and mortality $[1,3,4]$.

Finally in our study we observed an overall 30 days postoperative mortality of $1.5 \%$ (3/204), if we only take into account the patients $\leq 10 \mathrm{~kg}$ then mortality would be $3 / 131$ (2.3\%), while the now reported mortality in the European Association for Cardio-thoracic Surgery and the Society of Thoracic Surgeons Congenital Heart Surgery Database is 4\% [19] .

\section{$\underline{\text { Limitations }}$}

This is a non-blinded retrospective study. Because of logistic problems at our ICU 


\begin{abstract}
$30 \%$ of our patients had to be transported to another department for which they received additional sedation, the reason for additional sedation whether it was for transportation or for medical reasons was not traceable.
\end{abstract}

\title{
$\underline{\text { Conclusions and recommendations }}$
}

Since the optimal intraoperative blood glucose target range in pediatric patients during cardiac surgery for congenital heart disease remains unclear: "Conventional intraoperative high dose opioids and withholding glucose in intravenous fluids permits for a safe and moderate glucose control during pediatric cardiac surgery for congenital heart disease".

\section{Reference List}

1. Wintergerst KA, Buckingham B, Gandrud L, Wong BJ, Kache S, Wilson DM: Association of hypoglycemia, hyperglycemia, and glucose variability with morbidity and death in the pediatric intensive care unit. Pediatrics 2006, 118: 173179.

2. Polito A, Thiagarajan RR, Laussen PC, Gauvreau K, Agus MS, Scheurer MA et al.: Association between intraoperative and early postoperative glucose levels and adverse outcomes after complex congenital heart surgery. Circulation 2008, 118: 2235-2242.

3. Vlasselaers D, Milants I, Desmet L, Wouters PJ, Vanhorebeek I, van dH, I et al.: Intensive insulin therapy for patients in paediatric intensive care: a prospective, randomised controlled study. Lancet 2009, 373: 547-556.

4. Yates AR, Dyke PC, Taeed R, Hoffman TM, Hayes J, Feltes TF et al.: Hyperglycemia is a marker for poor outcome in the postoperative pediatric cardiac patient. Pediatr Crit Care Med 2006, 7: 351-355.

5. Ulate KP, Lima Falcao GC, Bielefeld MR, Morales JM, Rotta AT: Strict glycemic targets need not be so strict: a more permissive glycemic range for critically ill children. Pediatrics 2008, 122: e898-e904.

6. Finfer $\mathrm{S}$, Chittock DR, Su SY, Blair D, Foster D, Dhingra V et al.: Intensive versus conventional glucose control in critically ill patients. $N$ Engl J Med 2009, 360: 12831297. 
7. Floyd TF, Horak J: Con: Tight perioperative glycemic control. J Cardiothorac Vasc Anesth 2009, 23: 906-908.

8. Piper HG, Alexander JL, Shukla A, Pigula F, Costello JM, Laussen PC et al.: Real-time continuous glucose monitoring in pediatric patients during and after cardiac surgery. Pediatrics 2006, 118: 1176-1184.

9. Scohy TV, Bikker IG, Hofland J, de Jong PL, Bogers AJ, Gommers D: Alveolar recruitment strategy and PEEP improve oxygenation, dynamic compliance of respiratory system and end-expiratory lung volume in pediatric patients undergoing cardiac surgery for congenital heart disease. Paediatr Anaesth 2009, 19: 1207-1212.

10. Scohy TV, Gommers D, Jan ten Harkel AD, Deryck Y, McGhie J, Bogers AJ: Intraoperative evaluation of micromultiplane transesophageal echocardiographic probe in surgery for congenital heart disease. Eur J Echocardiogr 2007, 8: 241-246.

11. Preissig CM, Rigby MR, Maher KO: Glycemic control for postoperative pediatric cardiac patients. Pediatr Cardiol 2009, 30: 1098-1104.

12. Lacour-Gayet F, Clarke D, Jacobs J, Comas J, Daebritz S, Daenen W et al.: The Aristotle score: a complexity-adjusted method to evaluate surgical results. Eur J Cardiothorac Surg 2004, 25: 911-924.

13. Jenkins KJ, Gauvreau K, Newburger JW, Spray TL, Moller JH, Iezzoni LI: Consensusbased method for risk adjustment for surgery for congenital heart disease. $J$ Thorac Cardiovasc Surg 2002, 123: 110-118.

14. DeCampli WM, Olsen MC, Munro HM, Felix DE: Perioperative hyperglycemia: effect on outcome after infant congenital heart surgery. Ann Thorac Surg 2010, 89: 181-185.

15. Bell C, Hughes CW, Oh TH, Donielson DW, O'Connor T: The effect of intravenous dextrose infusion on postbypass hyperglycemia in pediatric patients undergoing cardiac operations. J Clin Anesth 1993, 5: 381-385.

16. Duncan HP, Cloote A, Weir PM, Jenkins I, Murphy PJ, Pawade AK et al.: Reducing stress responses in the pre-bypass phase of open heart surgery in infants and young children: a comparison of different fentanyl doses. Br J Anaesth 2000, 84: 556-564.

17. Anand KJ, Hickey PR: Halothane-morphine compared with high-dose sufentanil for anesthesia and postoperative analgesia in neonatal cardiac surgery. $N$ Engl $\mathrm{J} \mathrm{Med}$ 1992, 326: 1-9.

18. Ellis DJ, Steward DJ: Fentanyl dosage is associated with reduced blood glucose in pediatric patients after hypothermic cardiopulmonary bypass. Anesthesiology 1990, 72: $812-815$.

19. Jacobs JP, Jacobs ML, Maruszewski B, Lacour-Gayet FG, Clarke DR, Tchervenkov CI et al.: Current status of the European Association for Cardio-Thoracic Surgery and the Society of Thoracic Surgeons Congenital Heart Surgery Database. Ann Thorac Surg 2005, 80: 2278-2283. 
Table 3: Data of patients with hyperglycemia $>180 \mathrm{mg} / \mathrm{dl}$ at ICU arrival.

$\mathrm{ASD}=$ atrial septal defect; $\mathrm{Switch}=$ arterial switch operation; ALCAPA= abnormal left coronary artery from the pulmonary artery; VSD= ventricular septal defect; $\mathrm{CoA}=$ aortic coarctation; $\mathrm{PDA}=$ patent ductus arteriosus; $\mathrm{AP}$ window=aortic pulmonary window; $\mathrm{TOF}=$ tetralogy of Fallot; corr. Ao Arch= correction aortic arch, $\mathrm{RACHS}=$ risk adjustment for surgery for congenital heart disease, $\mathrm{CPB}=$ cardiopulmonary bypass, AoX= Aortic crossclamping, $\mathrm{DHCA}=$ deep hypothermic cardiac arrest, $\mathrm{ACP}=$ antegrade cerebral perfusion, glc $\mathrm{IC}=$ blood glucose on Intensive Care arrival.

\section{Table 4: Logistic regression analysis}

$\mathrm{RACHS}=$ risk adjustment for surgery for congenital heart disease, $\mathrm{CPB}=$ cardiopulmonary bypass, AoX= Aortic crossclamping, $\mathrm{DHCA}=$ deep hypothermic cardiac arrest, $\mathrm{ACP}=$ antegrade cerebral perfusion, glc $\mathrm{IC}=$ blood glucose on Intensive Care arrival. $\mathrm{B}=$ sample regression coefficient, $\mathrm{S} . \mathrm{E} .=$ standard error, Sig.= two-sided $\mathrm{P}$ value or observed significance level, $\operatorname{Exp}(B)=$ exponentiation of the B coefficient, C.I.=confidence interval.

Table 5: Correlation analysis results of intraoperative blood glucose versus LOS, ICU days, extubation time and mortality.

Table 6: Linear regression analysis results: Lower $(<60$ and $<75 \mathrm{mg} / \mathrm{dl})$ and higher intraoperative blood glucose levels $(>140$ and $>180 \mathrm{mg} / \mathrm{dl})$ versus LOS, ICU stay, mortality or extubation time. 
$\mathrm{B}=$ sample regression coefficient, S.E. $=$ standard error, Sig. $=$ two-sided $\mathrm{P}$ value or observed significance level, Beta $=$ standardized coefficient, C.I.=confidence interval.

Figure 1: Intraoperative and ICU arrival blood glucose levels.

Figure 2: Blood glucose levels at ICU arrival versus ICU days. 


\begin{tabular}{|c|c|}
\hline Age: $n=204$ & \\
\hline Median (IQR) & $221(81-965)$ \\
\hline$<30$ days $(\mathrm{N})$ & 22 \\
\hline$>30$ days $<1$ year $(\mathrm{N})$ & 101 \\
\hline$>1$ year & 81 \\
\hline Weight (kg): n=204 & \\
\hline Median (IQR) & $8(4.5-13.3)$ \\
\hline$<5 \mathrm{~kg}(\mathrm{~N})$ & 59 \\
\hline$>5 \mathrm{~kg}(\mathrm{~N})$ & 145 \\
\hline Aristotle score: $\mathrm{n}=\mathbf{2 0 4}$ & \\
\hline Median (IQR) & $8(6-9)$ \\
\hline |RACHS score: $\mathbf{n = 2 0 4}$ & \\
\hline Median (IQR) & $2(2-3)$ \\
\hline Cyanotic lesions/ acyanotic lesions & $95 / 109$ \\
\hline CPB (min): $n=204$ & \\
\hline Median (IQR) & $82(52.5-107)$ \\
\hline AOX (min): $n=204$ & \\
\hline Median (IQR) & $47(26-67.5)$ \\
\hline DHCA (min): $n=9$ & \\
\hline Median (IQR) & $53(21.5-70.5)$ \\
\hline CPB temp (Celsius): $n=204$ & \\
\hline Median (IQR) & $30.3(28.7-33.5)$ \\
\hline Extubation (hours): $n=142$ & . \\
\hline Median (IQR) & $7.1(4.9-10.18)$ \\
\hline LOS (days); n=201 & 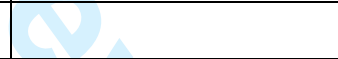 \\
\hline Median (IQR) & $8(7-15)$ \\
\hline IC stay (days): $n=201$ & 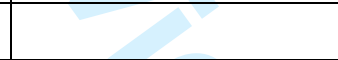 \\
\hline Median (IQR) & $1(1-4)$ \\
\hline Blood glucose pre CPB (mg/dl): $n=204$ & +2 \\
\hline Median (IQR) & $86(75-103)$ \\
\hline Highest blood glc intraoperative (mg/d & \\
\hline Median (IQR) & $160(129-194)$ \\
\hline Blood glucose ICU (mg/dl): n=204 & \\
\hline Mean (SD) & $129(35)$ \\
\hline Median (IQR) & $126(106-151)$ \\
\hline
\end{tabular}




\section{Table: Individual procedures by RACHS-1 category}

Risk Category 1

ASD closure (29)

Coarctation repair with left-left shunt at age $>30 \mathrm{~d}$ (1)

Partially anomalous pulmonary venous return repair (2)

Sinus venosus atrial septal defect closue (2)

Risk Category 2

Aortic-pulmonary window repair and ASD closure (1)

Aortic valvuloplasty at age $>30 \mathrm{~d}(1)$

Partial cavo-pulmonary connection (16)

Pulmonary valvuloplasty (5)

Pulmonary valve replacement (1)

Total repair of TOF (21)

VSD closure (29)

VSD and ASD closure (9)

VSD closure and pulmonary valvuloplasty (2)

VSD closure and right vemtricle infundibulectomy (5)

VSD closure and subaortic stenosis (3)

Risk Category 3

Anomalous left coronary artery from pulmonary artery reimplantation (1)

Aortic- and mitral valvuloplasty (1)

Aortic-pulmonary window (2)

Arterial switch operation (3)

CAVSD repair (19)

Coarctation repair and VSD closure (2)

Heart transplantation (2)

Intracardiac tumor excision (1)

Left Ventricular Assist Device (1)

Mitral valvuloplasty (1)

Pulmonary artery banding and VSD closure (1)

Pulmonary valve replacement and VSD closure (1)

Ross procedure (1)

Tricuspid valvuloplasty (1)

TOF repair with pulmonary atresia (1)

Total cavo-pulmonary connection (16)

Tricuspid valve repositioning for Ebstein anomaly at age $>30 \mathrm{~d}$ (1)

Risk Category 4

Atrial septectomy (1)

Arterial switch operation and VSD closure (6)

Hypoplastic aortic arch repair and VSD closure (2)

Interrupted aortic arch repair (1)

TAPVR repair at age $<30 \mathrm{~d}(5)$

TAPVR, CAVSD and TGA repair (1)

Risk Category 5

Damus-Kaye-Stansel procedure (1)

Norwood operation (5)

$\mathrm{ASD}=$ atrial septal defct, $\mathrm{CAVSD}=$ complete atrioventricular septal defect, TAPVR=Total anomalous pulmonary venous return, $\mathrm{TGA}=$ transposition of great arteries, $\mathrm{TOF}=$ tetralogy of Fallot, VSD=ventricular septal defect. 
 \\ Page 20 of 26}

Pediatric Anesthesia

17

19




\begin{tabular}{|c|c|c|c|c|c|c|c|c|c|c|}
\hline gender & Age & $\begin{array}{c}\text { Weight } \\
\text { (kg) }\end{array}$ & sort & $\begin{array}{c}\text { Aristotle } \\
\text { Score }\end{array}$ & $\begin{array}{c}\text { RACHS } \\
\text { score }\end{array}$ & $\begin{array}{l}\text { CPB } \\
\text { time } \\
\text { (min) }\end{array}$ & $\begin{array}{c}\text { AOX } \\
(\min )\end{array}$ & $\begin{array}{l}\text { CPB } \\
\text { temp }\end{array}$ & $\begin{array}{c}\text { DHCA/ACP } \\
(\min )\end{array}$ & $\begin{array}{c}\text { glc IC } \\
(\mathrm{mg} / \mathrm{dl})\end{array}$ \\
\hline M & $1 \mathrm{~m} 3 \mathrm{~d}$ & 13.4 & ASD & 3 & 1 & 45 & 20 & 35.1 & & 181.8 \\
\hline $\mathrm{F}$ & $4 d$ & 2.5 & Switch+ASD & 13 & 4 & 148 & 93 & 26.2 & $4 / 0$ & 196.2 \\
\hline M & $3 m 3 d$ & 5.9 & ALCAPA & 10 & 3 & 224 & 156 & 25.8 & & 185.4 \\
\hline M & $14 d$ & 3.8 & VSD,ASD,CoA,PDA & 15 & 3 & 104 & 53 & 26.1 & $21 / 0$ & 199.8 \\
\hline M & $2 m$ & 2.5 & $\begin{array}{l}\text { PDA, AP-window, } \\
\text { Atrial Septal } \\
\text { Fenestartion. }\end{array}$ & 9.8 & 2 & 65 & 30 & 28.4 & & 201.6 \\
\hline M & $1 \mathrm{~m} 16 \mathrm{~d}$ & 4.3 & TOF & 8 & 2 & 156 & 94 & 28.6 & & 219.6 \\
\hline M & $5 \mathrm{~m} 2 \mathrm{~d}$ & 5.2 & TOF & 8 & 2 & 85 & 45 & 30.7 & & 190.8 \\
\hline M & $6 d$ & 3.8 & VSD+corr. Ao Arch & 13 & 4 & 126 & 56 & 22.1 & & 187.2 \\
\hline M & $4 d$ & 3.4 & Norwood & 14.5 & 6 & 197 & 110 & 17.2 & $82 / 59$ & 275.4 \\
\hline $\mathrm{F}$ & $3 m 11 d$ & 5.4 & TOF+corr. Ao Arch & 14 & 5 & 111 & 66 & 21.5 & $24 / 0$ & 181.8 \\
\hline M & $7 d$ & 3 & Norwood & 14.5 & 6 & 162 & 100 & 25.5 & $54 / 34$ & 286.2 \\
\hline M & $13 d$ & 3.1 & ASD+PDA & 6 & 1 & 102 & 45 & 29.3 & & 196.2 \\
\hline
\end{tabular}


95.0\% C.I.for

B S.E. Sig. $\operatorname{Exp}(B) \operatorname{EXP}(B)$

$\begin{array}{lcccccc} & & & & & \text { Lower } & \text { Upper } \\ \text { Weight } & -0.358 & 0.144 & \mathbf{0 . 0 1 3} & 0.699 & 0.527 & 0.927 \\ \text { Age_days } & -0.018 & 0.007 & \mathbf{0 . 0 0 8} & 0.982 & 0.969 & 0.995 \\ \text { Aristotle_Score } & 0.317 & 0.101 & \mathbf{0 . 0 0 2} & 1.373 & 1.126 & 1.675 \\ \text { RACHS_score } & 0.633 & 0.223 & \mathbf{0 . 0 0 4} & 1.884 & 1.217 & 2.916 \\ \text { CPB_time } & 0.006 & 0.003 & 0.07 & 1.006 & 1 & 1.012 \\ \text { AoXmin } & 0.12 & 0.006 & 0.068 & 1.012 & 0.999 & 1.024 \\ \text { gluc_pre } & 0.028 & 0.01 & \mathbf{0 . 0 0 4} & 1.028 & 1.009 & 1.048 \\ \text { CPB temp } & -0.296 & 0.066 & \mathbf{0} & 0.744 & 0.654 & 0.846 \\ \text { DHCA } & 0.4 & 0.014 & \mathbf{0 . 0 0 4} & 0.5 & 1.012 & 1.069\end{array}$




\begin{tabular}{|l|c|c|}
\hline Correlation & Spearman's rho & Significance (2-tailed) \\
\hline & & \\
\hline Highest intraop Glc / ICU days & 0.199 & 0.005 \\
\hline Highest intraop Glc / LOS & 0.197 & 0.005 \\
\hline Highest intraop Glc / ICU glc & 0.284 & 0.0001 \\
\hline Highest intraop Glc / Extubation time & 0.259 & 0.0001 \\
\hline Highest intraop Glc / mortality & 0.132 & $\mathrm{NS}$ \\
\hline & & $\mathrm{NS}$ \\
\hline$>140 \mathrm{mg} / \mathrm{dl}$ intraop glc / LOS & 0.14 & $\mathrm{NS}$ \\
\hline$>140 \mathrm{mg} / \mathrm{dl}$ intraop glc / ICU days & 0.102 & $\mathrm{NS}$ \\
\hline$>140 \mathrm{mg} / \mathrm{dl}$ intraop glc / extubation time & 0.143 & $\mathrm{NS}$ \\
\hline$>140 \mathrm{mg} / \mathrm{dl}$ intraop glc / mortality & 0.09 & $\mathrm{NS}$ \\
\hline & & 0.038 \\
\hline$>180 \mathrm{mg} / \mathrm{dl}$ intraop glc / LOS & 0.137 & 0.015 \\
\hline$>180 \mathrm{mg} / \mathrm{dl}$ intraop glc / ICU days & 0.147 & 0.012 \\
\hline$>180 \mathrm{mg} / \mathrm{dl}$ intraop glc / extubation time & 0.203 & 0.175 \\
\hline$>180 \mathrm{mg} / \mathrm{dl}$ intraop glc / mortality & &
\end{tabular}




\begin{tabular}{|c|c|c|c|c|c|c|}
\hline \multirow[b]{2}{*}{ Linear Regression } & \multirow[b]{2}{*}{ B } & \multirow[b]{2}{*}{ Std Error } & \multirow[b]{2}{*}{ Beta } & \multirow[b]{2}{*}{ Sign. } & \multicolumn{2}{|c|}{ 95\% C.I. } \\
\hline & & & & & lower & higher \\
\hline$<60 \mathrm{mg} / \mathrm{dl}$ intraop glc / LOS & -1.949 & 4.285 & -0.035 & 0.65 & -10.399 & 6.501 \\
\hline$<60 \mathrm{mg} / \mathrm{dl}$ intraop glc / ICU days & 0.154 & 1.863 & 0.006 & 0.934 & -3.519 & 3.828 \\
\hline$<60 \mathrm{mg} / \mathrm{dl}$ intraop glc / extubation & 1.715 & 2.2 & 0.071 & 0.437 & -2.635 & 6.066 \\
\hline$<60 \mathrm{mg} / \mathrm{dl}$ intraop glc / mortality & -0.004 & 0.038 & -0.009 & 0.91 & -0.08 & 0.071 \\
\hline$<75 \mathrm{mg} /$ dl intraop glc / LOS & 1.884 & 2.711 & 0.063 & 0.488 & -3.461 & 7.23 \\
\hline$<75 \mathrm{mg} /$ dl intraop glc / ICU days & 0.795 & 1.178 & 0.06 & 0.501 & -1.529 & 3.118 \\
\hline$<75 \mathrm{mg} /$ dl intraop glc / extubation & 0.741 & 1.169 & 0.667 & 0.528 & -1.572 & 3.053 \\
\hline$<75 \mathrm{mg} / \mathrm{dl}$ intraop glc / mortality & -0.025 & 0.024 & -0.089 & 0.325 & -0.072 & 0.024 \\
\hline$>140 \mathrm{mg} / \mathrm{dl}$ intraop glc / LOS & 2.492 & 1.991 & 0.088 & 0.212 & -1.435 & 6.418 \\
\hline$>140 \mathrm{mg} / \mathrm{dl}$ intraop glc / ICU days & -0.943 & 1.214 & -0.77 & 0.438 & -3.337 & 1.45 \\
\hline$>140 \mathrm{mg} / \mathrm{dl}$ intraop glc / extubation & 1.258 & 0.852 & 0.124 & 0.142 & -0.426 & 2.942 \\
\hline$>140 \mathrm{mg} / \mathrm{dl}$ intraop glc / mortality & 0.023 & 0.018 & 0.9 & 0.199 & -0.12 & 0.58 \\
\hline & & & & & & \\
\hline$>180 \mathrm{mg} / \mathrm{dl}$ intraop glc / LOS & 2.45 & 2.05 & 0.84 & 0.233 & -1.593 & 6.493 \\
\hline$>180 \mathrm{mg} / \mathrm{dl}$ intraop glc / ICU days & 0.015 & 0.01 & 0.118 & 0.126 & -0.004 & 0.062 \\
\hline$>180 \mathrm{mg} / \mathrm{dl}$ intraop glc / extubation & 1.319 & 0.877 & 0.126 & 0.135 & -0.414 & 3.053 \\
\hline$>180 \mathrm{mg} / \mathrm{dl}$ intraop glc / mortality & 0.027 & 0.17 & 0.106 & 0.11 & -0.006 & 0.06 \\
\hline
\end{tabular}


intraoperative blood glucose

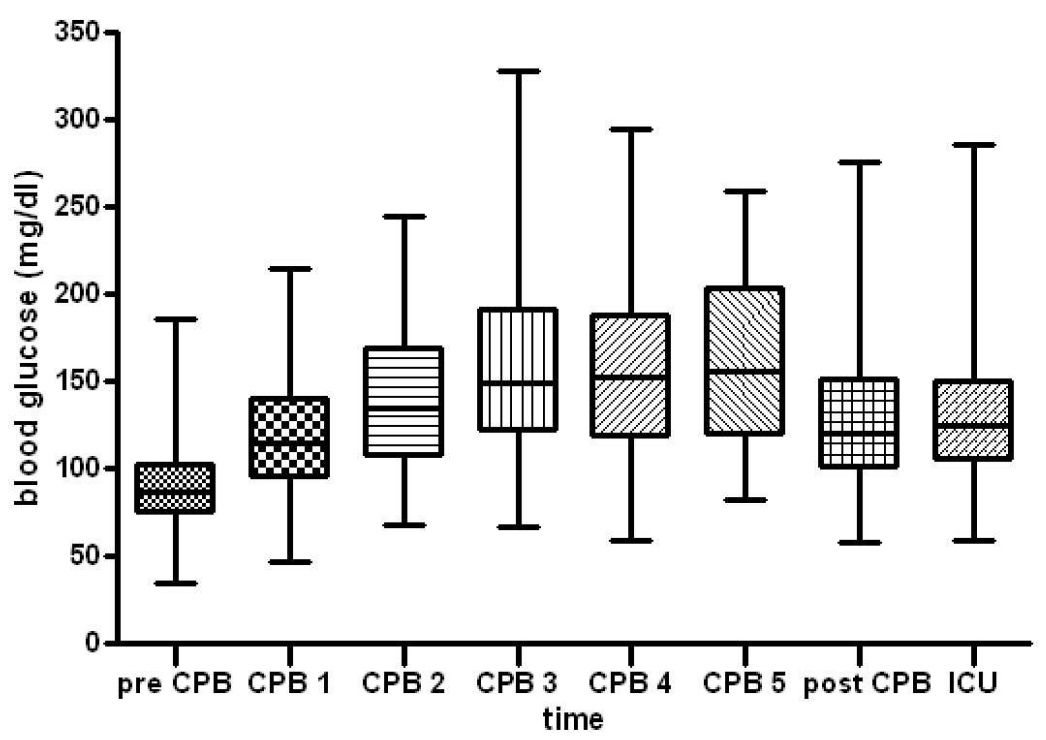

$355 \times 305 \mathrm{~mm}(96 \times 96 \mathrm{DPI})$ 
1

2

3

4

5

6

7

8

9

10

11

12

13

14

15

16

17

18

19

20

21

22

23

24

25

26

27

28

29

30

31

32

33

34

35

36

37

38

39

40

41

42

43

44

45

46

47

48

49

50

51

52

53

54

55

56

57

58

59

60

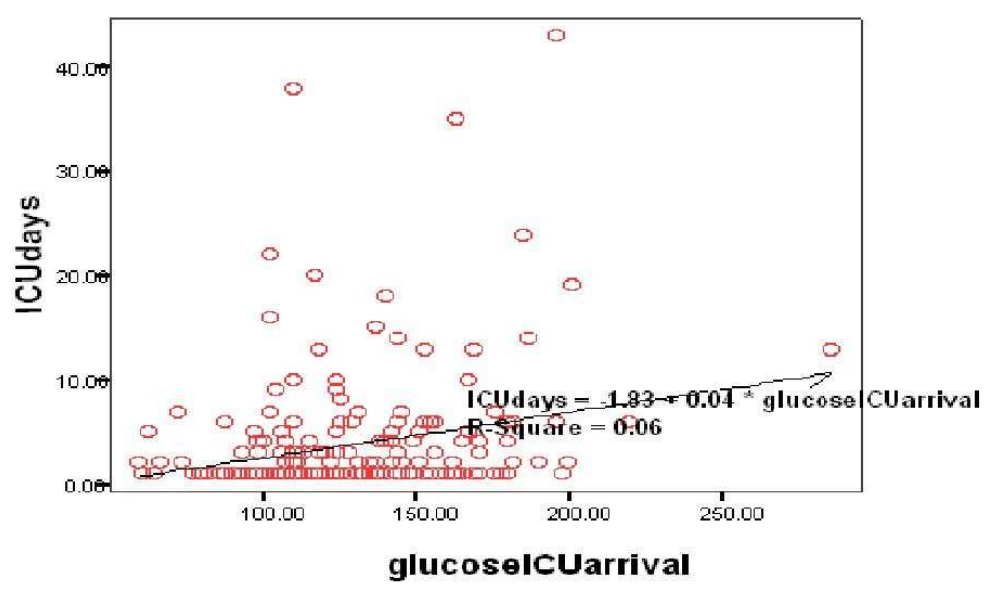

$318 \times 201 \mathrm{~mm}(96 \times 96$ DPI) 